\title{
TEMUAN FRAGMEN GERABAH SEBAGAI INDIKASI PERMUKIMAN KUNO DI SITUS BOROBUDUR
}

\section{POTTERY SHERDS AS AN INDICATOR OF OLD SETTLEMENT IN BOROBUDUR SITE}

\author{
Agni Sesaria Mochtar \\ Balai Arkeologi Yogyakarta \\ agnimochtar@yahoo.co.id
}

\begin{abstract}
Borobudur temple has been famously known as one of the Indonesian heritage masterpiece. Various aspects of it had been studied thoroughly since the beginning of 20th century A.D. Those studies tended to be monumental centric, giving less attention to the cultural context of the temple and its surroundings. Settlement in the nearby places is one of the topics which not have been studied much yet; leaving a big question about how the settlement supported continuity of many activities in the temple, or even the other way around; how the temple affected the settlement. There is only a few data about old settlement found in situ in Borobudur site, only abundance of pottery sherds. The analysis applied on to the potteries find during the 2012 excavation had given some information about the old settlement in Borobodur site. The old settlement predicted as resided in the south west area, in the back side of the monument.
\end{abstract}

Keywords: Pottery, Borobudur, Old settlement

\begin{abstract}
ABSTRAK
Candi Borobudur telah lama dikenal sebagai salah satu mahakarya warisan budaya Indonesia. Berbagai penelitian mengenai berbagai aspek yang berkaitan dengannya telah banyak dilakukan sejak awal abad ke-20 M. Akan tetapi, penelitian yang telah dilakukan cenderung terpusar pada bangunan candi itu sendiri dan tidak banyak membahas Candi Borobudur sebagai bagian dari sebuah konteks kebudayaan yang mengelilinginya. Salah satu topik yang belum dibahas adalah tentang permukiman yang mendukung kelangsungan aktivitas di Candi Borobudur, ataupun sebaliknya; permukiman yang sangat dipengaruhi oleh keberadaan Candi Borobudur. Tidak banyak data in situ yang masih dapat diperoleh dari Situs Borobudur untuk mengungkap permukiman kuna di sana. Akan tetapi, analisis terhadap fragmen-fragmen gerabah yang ditemukan di Situs Borobudur pada kegiatan ekskavasi tahun 2012 memberikan gambaran tentang permukiman kuno di situs tersebut. Permukiman kuno tersebut diperkirakan berada di sisi barat daya candi.
\end{abstract}

Kata kunci: Gerabah, Borobudur, Permukiman kuno

Tanggal masuk : 21 September 2013

Tanggal diterima : 24 November 2013 


\section{PENDAHULUAN}

Gerabah adalah istilah yang lebih umum digunakan di Indonesia untuk merujuk tembikar (earthenware), istilah untuk barang-barang yang terbuat dari tanah liat bakar. Gerabah merupakan salah satu kajian penting dalam arkeologi terutama sebagai indikator permukiman masa lampau. Di Indonesia gerabah mulai dikenal sejak sekitar 2.500-1.500 tahun sebelum Masehi, ketika tradisi bercocok tanam mulai muncul dan kebutuhan akan tempat penyimpanan mulai dirasakan (Atmosudiro 1998, 1). Gerabah menjadi penemuan yang efektif karena sifatnya yang tahan air dan tahan panas, sehingga sangat tepat digunakan untuk penyimpanan dan juga untuk kebutuhan masak-memasak.

Dalam perkembangannya, gerabah tidak lagi hanya memiliki fungsi kebutuhan keseharian tetapi juga fungsi religius. Wadah-wadah dari gerabah yang ditemukan pada beberapa situs prasejarah seperti Melolo, Gilimanuk, dan Plawangan digunakan sebagai wadah bekal kubur, seperti pada situs Gilimanuk (Soegondho 1999 , 17) dan juga sebagai tempat meletakkan jenasah atau tulang manusia pada sistem kubur tempayan (Soejono 1984, 74). Fungsi gerabah terus mengalami perkembangan setelah masuknya budaya Hindu-Buddha ke Indonesia. Gerabah yang dihasilkan tidak lagi terbatas pada wadah saja, tetapi mulai muncul bentuk-bentuk bukan wadah seperti figurin, celengan, miniatur bangunan, dan lampu minyak (celupak). Gerabah jenis ini banyak sekali ditemukan di Trowulan, Jawa Timur (Soegondho 1999, 36).

Fungsi-fungsi tersebut di atas menunjukkan dengan jelas keterkaitan erat antara gerabah sebagai artefak arkeologis dengan situs permukiman masa lampau. Demikian halnya dengan Situs Borobudur. Sebagai sebuah candi yang sangat besar, menarik untuk diteliti bagaimana masyarakat sekitar berinteraksi dengan bangunan candi tersebut pada masa pakainya. Apakah tidak mungkin jika keterkaitan antara keduanya kemudian membentuk sebuah permukiman di sekitar Candi Borobudur? Kegiatan ekskavasi yang dilaksanakan oleh Balai Arkeologi Yogyakarta pada akhir tahun 2012 difokuskan untuk meneliti jejak-jejak permukiman kuna di Situs Borobudur. Ekskavasi di sisi barat daya candi menunjukkan kemungkinan adanya permukiman kuna dengan ditemukannnya banyak fragmen gerabah.

Kondisi temuan gerabah yang fragmentaris sedikit menyulitkan dalam melakukan analisis konteks secara langsung dengan Candi Borobudur dan lingkungannya. Dengan demikian, dibutuhkan analisis yang lebih detil dari aspek formal temuan-temuan tersebut sebelum dilakukan analisis temporal dan spasialnya. Tulisan ini menguraikan analisis yang dilakukan terhadap temuan fragmen gerabah di Situs Borobudur, baik dari aspek formal, temporal, maupun spasial, agar dapat menjawab apakah permukiman kuna di Situs Borobudur benar-benar ada dilihat dari sudut pandang tinggalan artefaknya.

\section{METODE PENELITIAN}

Penelitian yang dilakukan untuk mengetahui adanya bekas permukiman kuna di Situs Borobudur berdasarkan temuan gerabahnya adalah sebuah penelitian deskriptif, dengan alur penalaran induktif. Penelitian ini menggambarkan berbagai aspek analisis terhadap temuan fragmen gerabah baik dari segi formal, temporal, maupun spasial. Analisis formal meliputi analisis bentuk, bahan, teknik dan motif hias, serta teknik penyelesaian permukaan. Analisis temporal dilakukan dengan analisis pertanggalan secara relatif. Sementara analisis spasial dilakukan dengan melihat konteks posisi temuan fragmen gerabah dalam perspektif ruang Situs Borobudur.

Proses pengambilan data dilakukan dengan ekskavasi sistematik di sisi barat daya Situs Borobudur, pada lokasi yang saat ini difungsikan sebagai lapangan Gunadharma. Ekskavasi dilakukan mengikuti sistem grid yang telah dibuat untuk kawasan Candi Borobudur dan sekitarnya. Setiap grid berukuran 10 meter x 10 meter dan dibagi menjadi kotak-kotak galian berukuran 2 meter $\times 2$ meter. Pada setiap grid dipilih beberapa kotak yang digali menggunakan sistem spit dengan kedalaman masing-masing spit $20 \mathrm{~cm}$. 


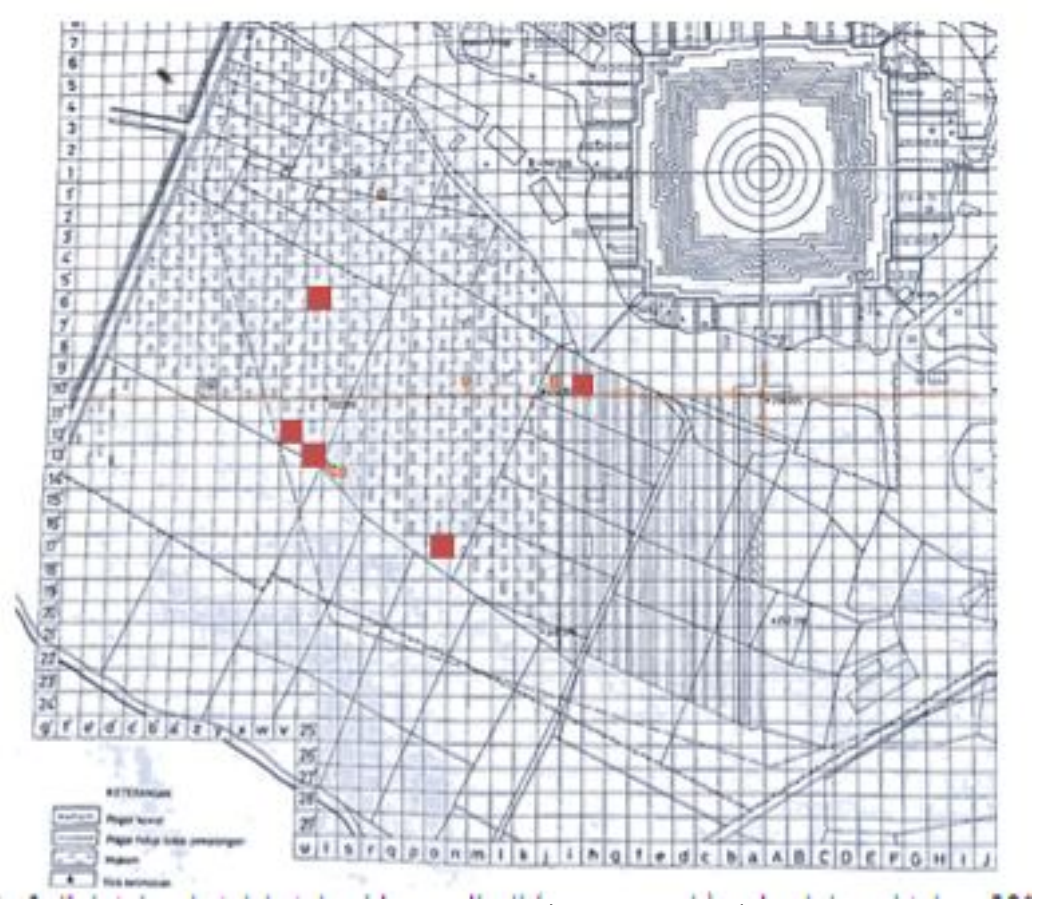

Peta 1. Keletakan kotak-kotak grid yang digali (warna merah) pada ekskavasi tăhun 2012 dengan Candi Borobudur. (Sumber: Tim Penyusun 2012)

Daerah ini pada tahun
pernah diteliti dalam rangka pembangunan taman wisata Borobudur. Tanah lapisan atas di lokasi tersebut telah teraduk dalam proses perataan lahan untuk kepentingan pariwisata. Data yang masih in situ ditemukan pada kedalaman $\pm 150-160 \mathrm{~cm}$, namun kondisinya sudah fragmentaris. Dari sekian banyak fragmen gerabah yang ditemukan, beberapa sampel diambil dengan teknik purposive sampling. Batasan yang digunakan adalah fragmen dari bagian gerabah yang masih bisa diamati bentuknya, seperti fragmen cerat, fragmen tutup, fragmen dasar, dan fragmen tepian, serta fragmen dengan motif hias. Setelah dianalisis, seluruh hasilnya dirangkum untuk menjawab permasalahan tentang keberadaan permukiman kuna di Situs Borobudur.

\section{KARAKTERISTIK BOROBUDUR}

GERABAH

\section{Bentuk}

Secara garis besar bentuk gerabah dibedakan menjadi 2 (dua), yaitu wadah dan bukan wadah. Jenis wadah dibedakan lagi menjadi wadah tertutup dan wadah terbuka. Fragmen gerabah yang ditemukan pada ekskavasi Situs Borobudur sebagian besar merupakan gerabah jenis wadah. Jenis wadah yang ditemukan terdiri dari mangkuk, bejana, kendi, dan periuk. Sementara jenis bukan wadah seperti figurin ataupun miniatur bangunan tidak ditemukan. Akan tetapi, dalam kegiatan survei di sekitar situs ditemukan sebuah celupak yang kondisinya masih utuh. Bentuk celupak ini cukup modern apabila dibandingkan dengan celupak yang banyak ditemukan pada masa klasik tua (abad VII-X M). Dengan demikian, konteks temporal temuan tersebut dengan permukiman pada masa pakai Candi Borobudur, masih perlu diteliti lebih lanjut. 


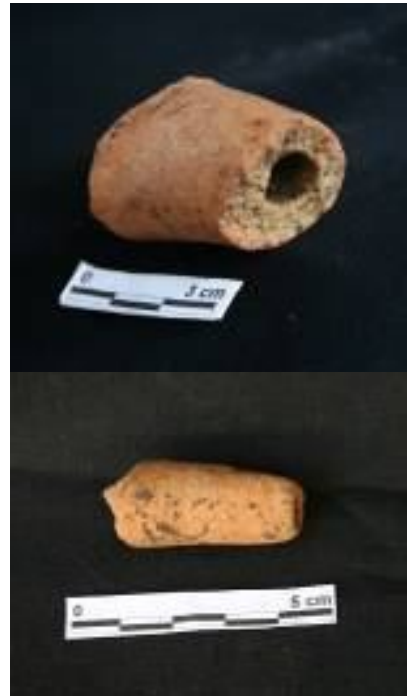

Foto 1. Fragmen cerat kendi

(Dok. Balar Yogyakarta)

Identifikasi jenis wadah berdasarkan fragmen gerabah yang ditemukan cukup sulit dilakukan. Ukuran fragmen-fragmen yang tidak terlalu besar menyulitkan dalam analisis bentuk. Akan tetapi, hal ini masih bisa diatasi dengan melakukan analisis bagian, diameter dan ketebalan fragmen. Bagian dengan ciri khas tertentu seperti fragmen cerat dengan mudah menunjukkan bahwa fragmen tersebut dulu merupakan bagian dari sebuah kendi. Fragmen bagian tepian digunakan untuk memperkirakan bentuk gerabah dengan cara diamati orientasi, diameter, dan ketebalannya, sehigga dapat diketahui apakah wadah tersebut berupa wadah terbuka, tertutup, atau tegak (Harkantiningsih, dkk (ed.) 1999, 59). Berdasarkan perkiraan ukuran diameter tepian dan ketebalan fragmen akan dapat ditentukan bentuk wadahnya. Diameter yang lebih kecil $(<25 \mathrm{~cm})$ dan profil yang tipis mengindikasikan wadah berbentuk mangkuk atau periuk, sementara diameter yang lebih besar $(>25 \mathrm{~cm})$ dan profil yang tebal mengindikasikan wadah berbentuk bejana.

Fragmen gerabah yang ditemukan pada ekskavasi tahun 2012 ini berukuran relatif kecil, sehingga sulit untuk dapat diperkirakan bentuk utuh dari wadahwadah tersebut. Akan tetapi, perbandingan dengan hasil analisis temuan gerabah dari ekskavasi tahun 1973-1974 dapat digunakan untuk memperkirakan bentuk utuh gerabah tersebut. Hal ini dimungkinkan karena konteks spasial dan temporal temuan tersebut sama, yaitu ditemukan di situs yang sama dan pada lapisan stratigrafi yang sama. Dengan demikian, diperkirakan juga memiliki bentuk yang sejenis.

Jenis wadah mangkuk yang pernah ditemukan di Situs Borobudur adalah mangkuk dengan motif hias, mangkuk tanpa motif hias, mangkuk dengan pegangan, dan mangkuk dengan tepian luar (Mundardjito 1978, 3-4). Pada ekskavasi tahun 2012 juga ditemukan fragmen gerabah yang menunjukkan keempat jenis bentuk mangkuk tersebut. Untuk wadah periuk, di Situs Borobudur dikenal ada dua jenis, yaitu periuk berbahu lebar dan periuk berdasar lebar. Selain itu, juga diketahui bahwa periuk Situs Borobudur memiliki ciri khas, yaitu memiliki bagian dasar yang cekung dan terdapat jejak jari tangan pada permukaan bagian dalam (Mundardjito 1978 , 3). Sayang sekali fragmen periuk yang ditemukan tahun 2012 ukurannya terlalu kecil untuk dapat mengetahui bentuk wadah periuknya. Akan tetapi, ditemukan beberapa fragmen badan yang menunjukkan jejak jari tangan pada permukaan bagian dalam, yang menunjukkan bahwa gerabah yang ditemukan merupakan gerabah khas dari Situs Borobudur. Sementara untuk wadah bejana telah diidentifikasi delapan jenis variasi, yaitu bejana dengan motif hias, bejana berkarinasi dengan tepian lebar, bejana berbadan panjang, bejana dengan bahu lebar dan berkarinasi, bejana bercerat, bejana berkarinasi tanpa leher, dan bejana dengan motif hias pada karinasi (Mundardjito 1978, 4). Fragmen bejana yang ditemukan pada ekskavasi 2012 hanya dapat mengindikasikan tipe bejana berkarinasi dengan tepian lebar. 

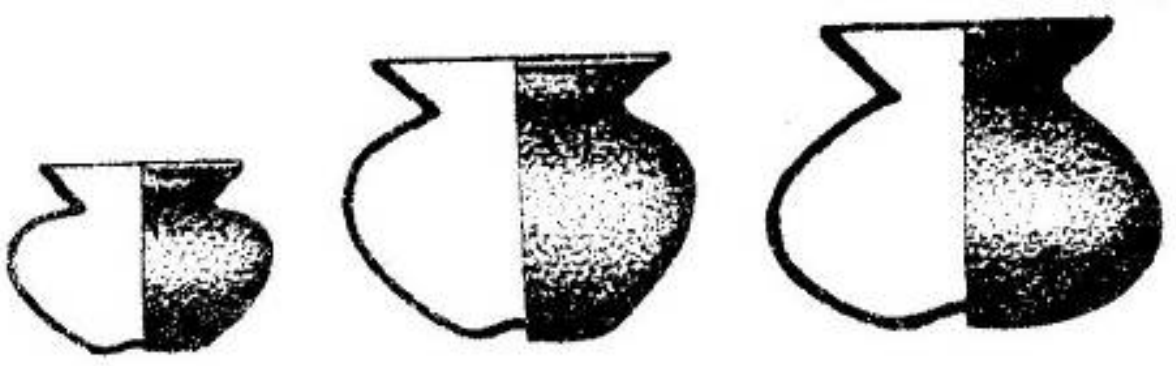

Gambar 1. Periuk yang ditemukan pada ekskavasi tahun 1973-1974

(Sumber: Mundardjito 1978)
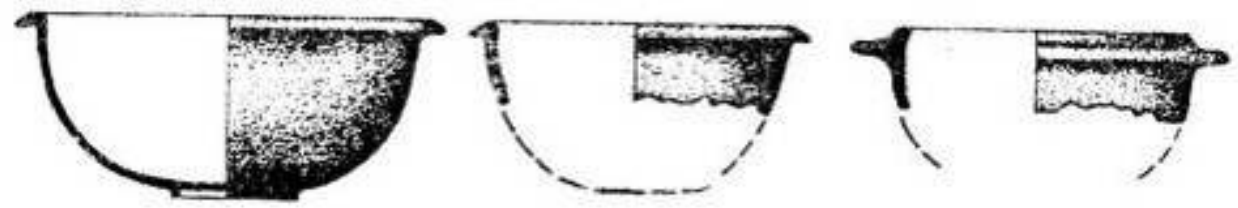

Gambar 2. Mangkuk yang ditemukan pada ekskavasi tahun 1973-1974

(Sumber: Mundardjito 1978)
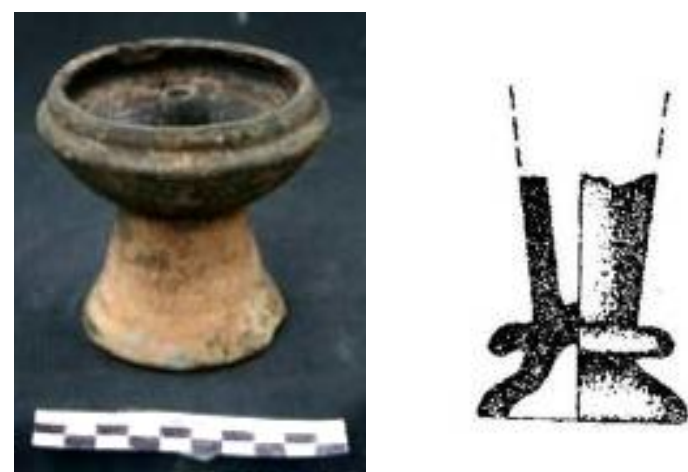

Gambar 3. Celupak yg ditemukan di sekitar Situs Borobudur (kiri - Dok. Balar Yogyakarta) dan fragmen kaki celupak yang ditemukan pada ekskavasi 1973-1974 (kanan - M undardjito 1978).

Sementara untuk celupak yang ditemukan di persawahan penduduk adalah jenis lampu minyak yang berkaki. Lampu minyak yang umum ditemui adalah jenis yang berbentuk menyerupai cawan kecil, akan tetapi jenis ini juga ditemukan pada ekskavasi tahun 19731974. Celupak yang ditemukan masih dalam kondisi utuh. Pada bagian bawah ditemukan bekas aplikasi cat sehingga diperkirakan celupak ini masih terus digunakan pada masa yang lebih muda, atau justru dibuat pada masa yang lebih muda. Akan tetapi, tetap dapat diperkirakan bahwa bentuk celupak tersebut telah dibuat dan dipakai pada masa pakai Candi Borobudur dan teknologinya masih terus berlanjut hingga masa yang lebih muda.

\section{Bahan}

Gerabah umumnya dibuat dari tanah liat yang biasanya dicampur dengan pasir, pecahan kerang, sekam padi, atau pecahan tembikar yang dihaluskan (grog). Berdasarkan bahan pembuatnya, gerabah dibagi menjadi gerabah halus dan gerabah kasar. Gerabah halus terbuat dari tanah liat berpartikel halus dan tanpa campuran, sementara gerabah kasar terbuat dari tanah liat berpartikel besar dan dicampur dengan bahan lain seperti pasir, pecahan kerang, sekam padi, atau pecahan tembikar yang telah dihaluskan (grog).

Mundardjito (1978) mengklasifikasi gerabah dari Situs Borobudur menjadi 'red ware' dan 'brown ware'. 'Red ware' merujuk pada gerabah yang dibuat dari tanah liat merah yang kompak/padat, sementara 'brown ware' merujuk pada 
gerabah yang dibuat dari tanah liat cokelat yang tidak padat. Berdasarkan klasifikasi tersebut Mundardjito mengungkapkan bahwa gerabah Borobudur diproduksi oleh setidaknya dua desa yang berbeda. Pada ekskavasi tahun 2012 ditemukan setidaknya tiga jenis gerabah berdasarkan warna bahan penyusunnya, yaitu gerabah krem (7/3 H5YR), gerabah coklat kemerahan (5/35/8 H5YR), dan gerabah abu-abu kecoklatan (3/2-4/2-5/2 H5YR). Warnawarna tersebut mengikuti skala Munsell. Hal ini memperkuat dugaan bahwa gerabah Situs Borobudur diproduksi oleh lebih dari dua desa yang berbeda.

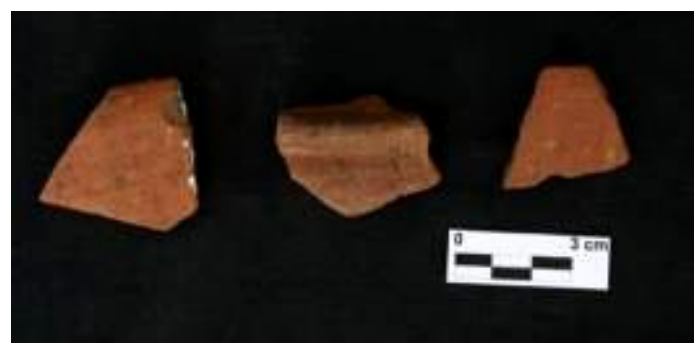

Foto 2. Fragmen gerabah berwarna merah (Dok. Balar Yogyakarta)

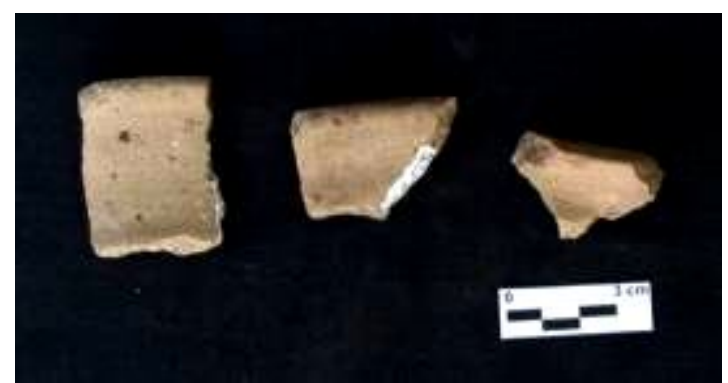

Foto 3. Fragmen gerabah berwarna krem (Dok. Balar Yogyakarta)

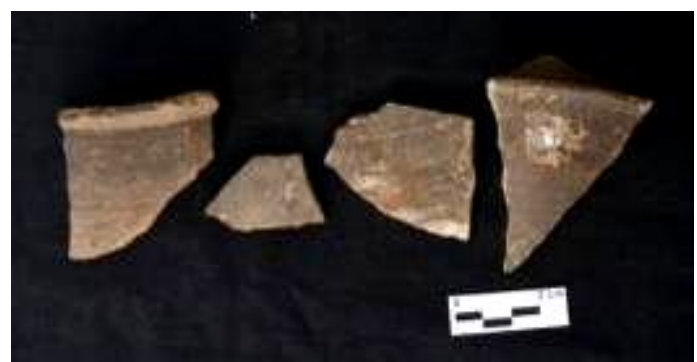

Foto 4. Fragmen gerabah berwarna abu-abu kecoklatan

(Dok. Balar Yogyakarta)

Bahan pembuat gerabah sering kali tidak murni tanah liat, tetapi diberi campuran untuk meningkatkan kualitas benda yang dihasilkan. Beberapa kualitas yang dapat ditingkatkan dengan penambahan bahan campuran (temper) adalah tingkat kekerasan dan porositas. Tingkat kekerasan gerabah Situs Borobudur menunjukkan angka 2.5 hingga 3. Sementara tingkat porositasnya adalah 14-28\%. Tingkat porositas tersebut menunjukkan bahwa kualitas gerabah Situs Borobudur termasuk baik, karena tingkat porositas $15-20 \%$ berarti baik dan tingkat porositas $20-25 \%$ termasuk sangat baik (http://geounhas06.wordpress.com/minya k-dan-gas-bumi/porositas-danpermeabilitas)

Tabel 1. Hasil analisis laboratoris gerabah Borobudur

\begin{tabular}{|c|c|c|c|c|c|}
\hline \multirow{2}{*}{ SAMPEL } & \multicolumn{5}{|c|}{ PARAMETER } \\
\cline { 2 - 6 } & WARNA & HARDNESS & POROSITAS & Pasir & Tanah liat \\
\hline 1 & Krem,7/3 H5YR,Pink & 3 & 15,52 & 16,67 & 83,33 \\
\hline 2 & $\begin{array}{c}\text { Coklat kemerahan, 5/3 } \\
\text { H5YR,reddish brown }\end{array}$ & 2.5 & 21,47 & 5,94 & 94,06 \\
\hline 3 & $\begin{array}{c}\text { Coklat kemerahan, 5/8 } \\
\text { H5YR,yellow red }\end{array}$ & 3 & 20,29 & 7,14 & 92,86 \\
\hline 4 & $\begin{array}{c}\text { Coklat kemerahan, 5/8 } \\
\text { H5YR,yellow red }\end{array}$ & 2.5 & 16,67 & 9,76 & 90,24 \\
\hline 5 & $\begin{array}{c}\text { Abu-abu kekuningan,4/2 } \\
\text { H5YR, drak reddish gray }\end{array}$ & 3 & 14,43 & 12,82 & 87,18 \\
\hline 6 & $\begin{array}{c}\text { Coklat keabu-abuan, 5/2 } \\
\text { H5YR,reddish gray }\end{array}$ & 2.5 & 28,79 & 20 & 80 \\
\hline 7 & $\begin{array}{c}\text { Abu-abu kecoklatan, 4/2 } \\
\text { H5YR,dark reddish gray }\end{array}$ & 2.5 & 14,5 & 9,84 & 90,16 \\
\hline
\end{tabular}




\begin{tabular}{|c|c|c|c|c|c|}
\hline 8 & $\begin{array}{c}\text { Abu-abu kecoklatan, 3/2 } \\
\text { H5YR,dark reddish brown }\end{array}$ & 2.5 & 13,85 & 10 & 90 \\
\hline 9 & $\begin{array}{c}\text { Coklat keabu-abuan, 3/2 } \\
\text { H5YR,dark reddish brown }\end{array}$ & 3 & 18,46 & 15,55 & 84,45 \\
\hline
\end{tabular}

(Analisis oleh Dekon Suyanto \& Hendi Susilo 2012)

\section{Teknik Pembuatan}

Gerabah yang terdapat di Situs Borobudur sebagian besar dibuat dengan teknik roda putar. Jejak penggunaan roda putar masih dapat dilihat pada permukaan gerabah yang menunjukkan striasi-striasi yang teratur. Beberapa fragmen gerabah juga menunjukkan jejak penggunaan teknik tatap-pelandas, tetapi bagian permukaan dalam fragmen tersebut tidak rata dan bergelombang, mengindikasikan jejak jari tangan pengrajin gerabah pembuatnya. Hal ini menunjukkan bahwa dalam proses pembuatan digunakan alat tatap tanpa pelandas. Fungsi pelandas digantikan dengan jari tangan pengrajin gerabah tersebut.

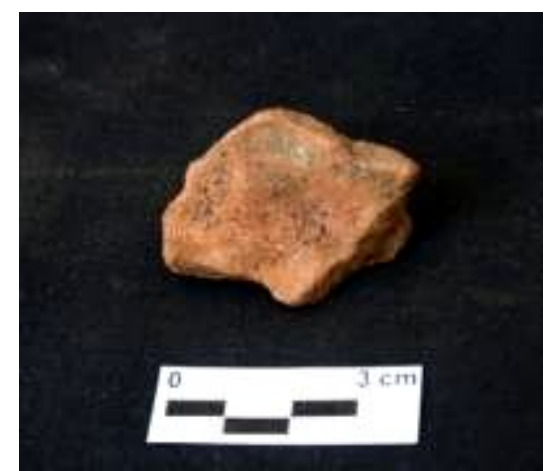

Foto 5. Jejak tekanan jari tangan pengrajin gerabah pada permukaan bagian dalam fragmen badan gerabah.

(Dok. Balar Yogyakarta)

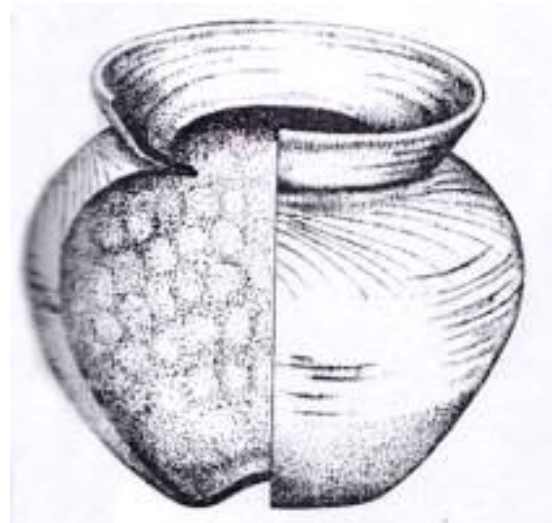

Gambar 4. Sketsa gerabah Borobudur yang menunjukkan striasi roda putar, diupam (streaky burnish), dan jejak jari tangan di permukaan bagian dalam.

(Sumber: M undardjito 1978)

\section{Penyelesaian Permukaan}

Setelah selesai dibentuk, sebuah gerabah perlu proses penyelesaian permukaan. Gerabah di Situs Borobudur menunjukkan jejak penyelesaian permukaan dengan teknik upam dan slip. Dua buah fragmen gerabah memiliki lapisan slip merah dari tanah liat, yang bahannya berbeda dengan tanah liat untuk membuat badan gerabah. Diperkirakan gerabah slip merah ini dibuat oleh pengrajin tersendiri atau dibuat dengan tujuan khusus. Sementara jejak teknik upam yang ditemukan pada fragmen gerabah adalah hasil upaman bergaris (streaky burnished). 


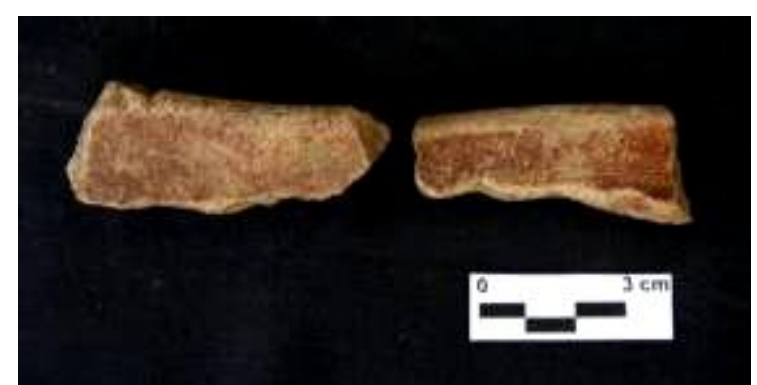

Foto 6. Fragmen gerabah yang menunjukkan penyelesaian permukaan dengan teknik slip berwarna merah. (Dok. Balar Yogyakarta)

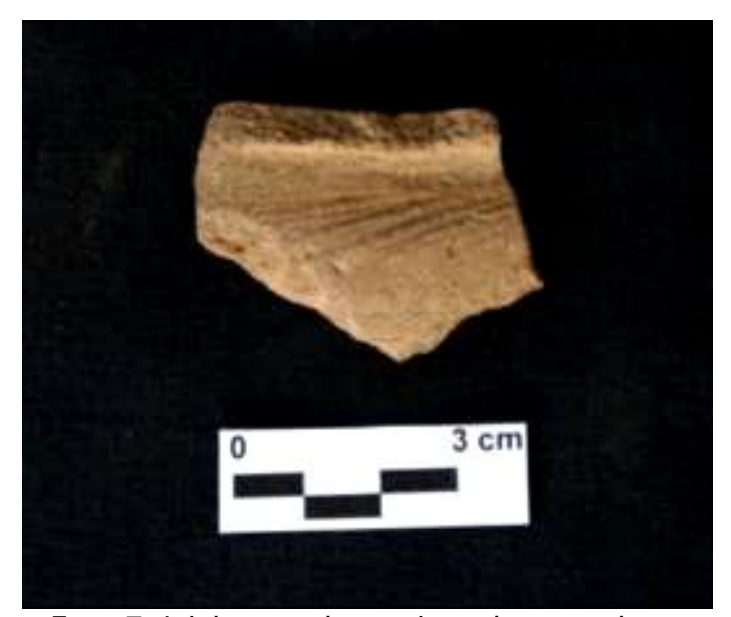

Foto 7. Jejak upam bergaris pada permukaan fragmen gerabah.

(Dok. Balar Yogyakarta) duri ikan, motif belah ketupat, dan motif garis sejajar horisontal ${ }^{\top}$. Hiasan yang dihasilkan dengan alat tatap ini diaplikasikan pada dua tipe wadah, yaitu mangkuk dan bejana, dan ditampakkan pada bagian tepian, badan, dan karinasi. Diperkirakan kedua jenis wadah ini memiliki fungsi yang khusus.

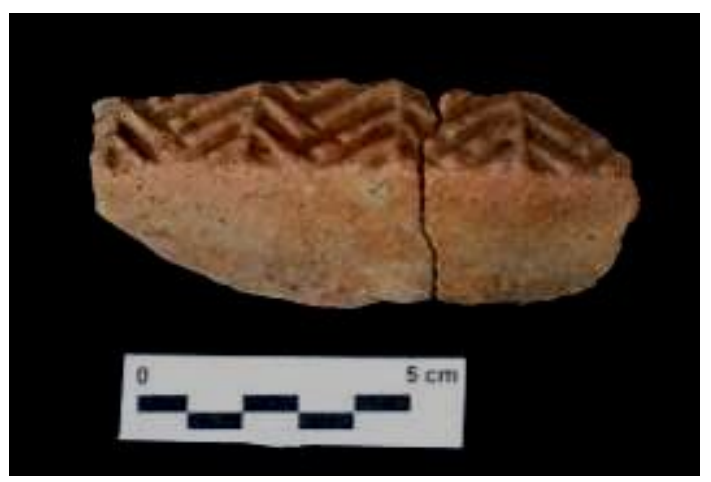

Foto 8. Motif geometris duri ikan pada fragmen karinasi (Dok. Balar Yogyakarta)

\section{Teknik Hias}

Dari seluruh temuan fragmen gerabah di Situs Borobudur sisi barat daya ini, hanya 15 fragmen yang memiliki hiasan dekoratif. Teknik hias yang diterapkan terdiri atas teknik tera, teknik tekan, teknik gores, dan teknik upam.

1. Teknik tera.

Hiasan dengan teknik tera diaplikasikan dengan cara menekan alat tatap ke bagian gerabah saat masih dalam kondisi agak basah (belum dijemur). Motif yang dihasilkan adalah motif-motif geometris. Motif geometris yang ditemukan pada fragmen gerabah dari Situs Borobudur adalah motif

\footnotetext{
${ }^{1}$ Definisi motif geometris merujuk pada Nitihaminoto 1986, 227-233
} 

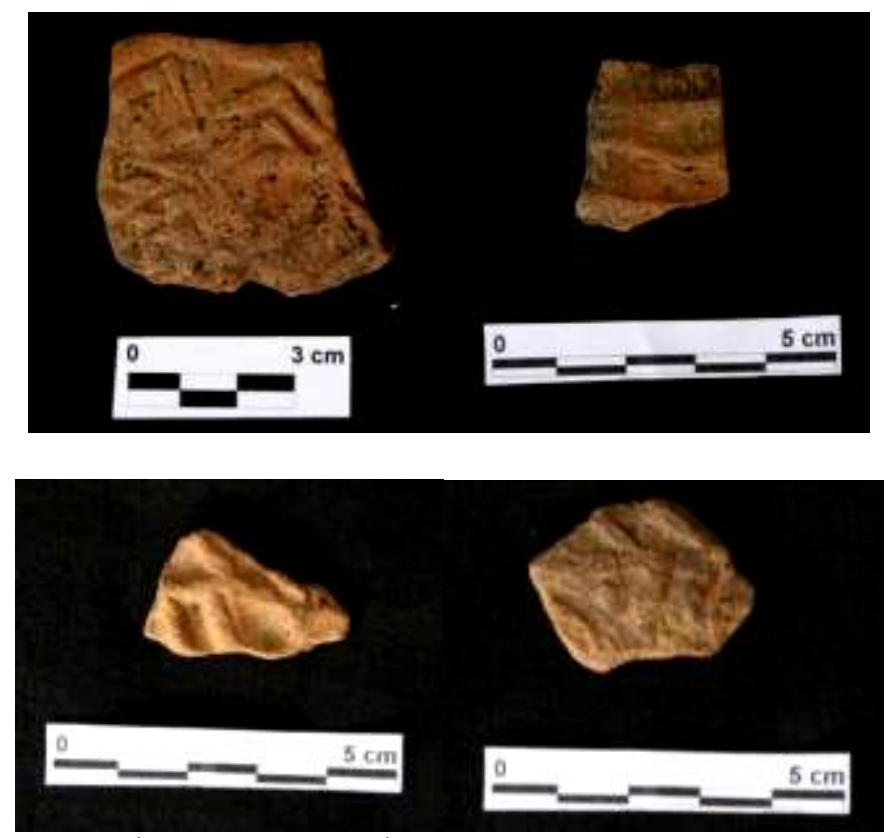

Foto 9. M otif geometris (searah jarum jam) huruf v, garis sejajar horisontal, duri ikan, dan duri ikan satu sisi, pada fragmen badan gerabah berwarna coklat kemerahan.

(Dok. Balar Yogyakarta)

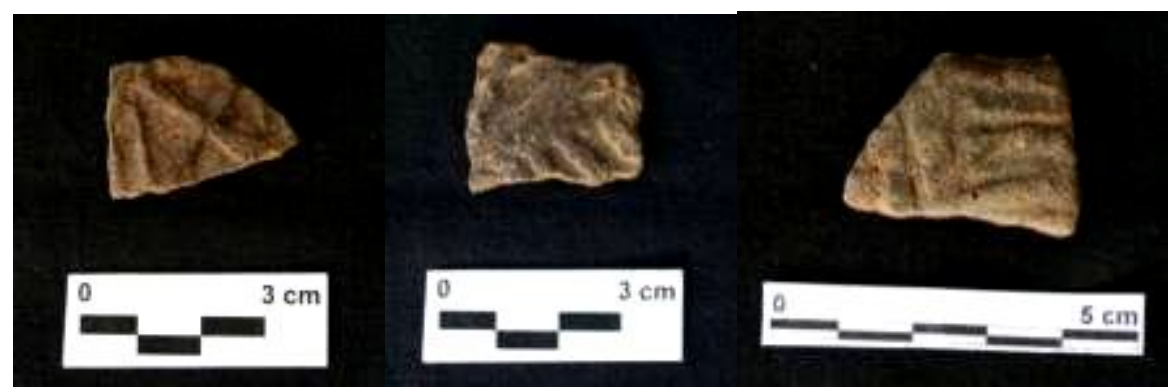

Foto 10. M otif geometris belah ketupat, duri ikan, dan garis sejajar pada fragmen badan gerabah berwarna abu-abu kecoklatan.

(Dok. Balar Yogyakarta)

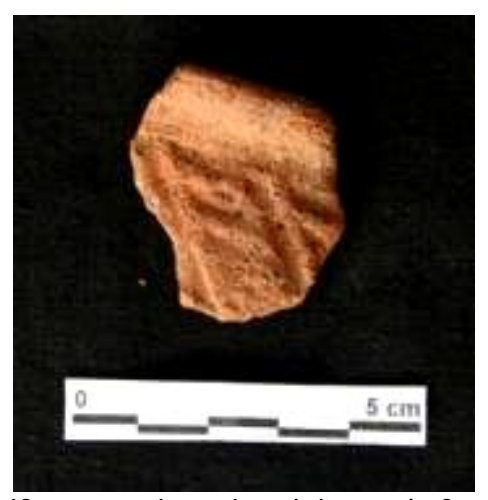

Foto 11. M otif geometris garis sejajar pada fragmen tepian.

(Dok. Balar Yogyakarta) 
2. Teknik tekan.

Hiasan dengan teknik tekan diaplikasikan baik menggunakan alat maupun dengan jari tangan. Hiasan dengan teknik tekan ditemukan pada fragmen karinasi bejana, membentuk motif tirai. Selain itu juga ditemukan hiasan teknik tekan pada fragmen tepian leher kendi.

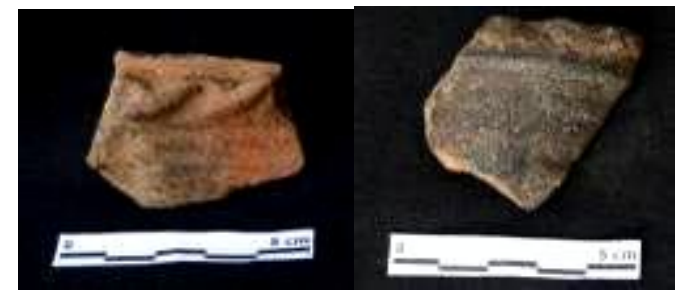

Foto 12. M otif pita yang diaplikasikan dengan teknik tekan.

(Dok. Balar Yogyakarta)

3. Teknik tempel.

Hiasan dengan teknik tempel diaplikasikan dengan cara menambahkan tanah liat ke bagian permukaan gerabah yang sudah jadi sebagai hiasan dengan bentuk tertentu. Penambahan ini dilakukan pada saat gerabah masih dalam kondisi basah. Fragmen gerabah dari Situs Borobudur yang memiliki hiasan tempel hanya dua buah. Diperkirakan hiasan tersebut hanya berfungsi sebagai ornamen karena ukurannya yang kecil dan berbentuk kerucut sehingga cukup sulit jika digunakan sebagai pegangan wadah.

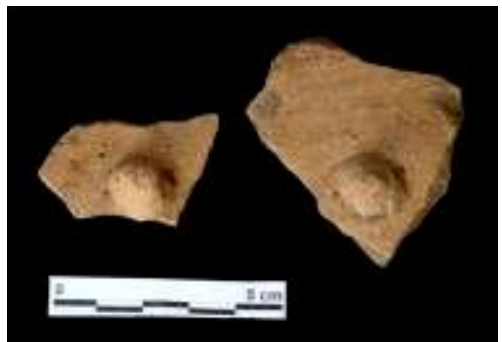

Foto 13. M otif hias dengan teknik tempel. (Dok. Balar Yogyakarta)

\section{GERABAH SEBAGAI INDIKATOR PERMUKIMAN KUNA DI SITUS BOROBUDUR}

Setelah analisis formal dilakukan pada temuan gerabah di Situs Borobudur diketahui bahwa fragmen-fragmen tersebut berasal dari berbagai jenis wadah untuk kebutuhan sehari-hari. Namun, informasi ini belum cukup untuk menjawab apakah benar adanya permukiman kuna di Situs Borobudur. Untuk menjawab apakah temuan gerabah tersebut sejaman dengan masa pakai Candi Borobudur diperlukan sebuah analisis temporal berupa penentuan pertanggalan dari temuan tersebut. Lebih lanjut, analisis spasial atas lokasi temuan dengan lingkungan sekitarnya diperlukan untuk memahami konteks budayanya.

\section{Pertanggalan (Dating)}

Fragmen gerabah yang ditemukan di Situs Borobudur sebagian besar ada pada spit 9-14 atau kedalaman 160-280 $\mathrm{cm}$ di bawah permukaan tanah. Beberapa fragmen juga ditemukan pada spit 1-4 (kedalaman 0-80 cm) dalam jumlah yang sedikit, diperkirakan berasal dari adukan tanah di atasnya akibat aktivitas perataan tanah tahun 1974. Fragmen gerabah mulai banyak ditemukan di bawah lapisan tipis abu vulkanik pada kedalaman $\pm 150-160 \mathrm{~cm}$. Lapisan abu vulkanik tersebut berwarna kuning kecoklatan, yang diperkirakan merupakan penanda berakhirnya masa pakai Candi Borobudur karena terjadinya letusan gunung berapi. Selain itu, pada kotak v.12'.VI pada spit 9 ditemukan sebuah batu andesit dan tatanan pecahan bata yang mengindikasikan bekas struktur bangunan dari masa pakai Candi Borobudur. Oleh karena fragmen gerabah ditemukan pada lapisan stratigrafi yang sama dengan temuan ini, maka dapat disimpulkan bahwa temuan fragmen gerabah memiliki konteks temporal yang sama dengan Candi Borobudur. 


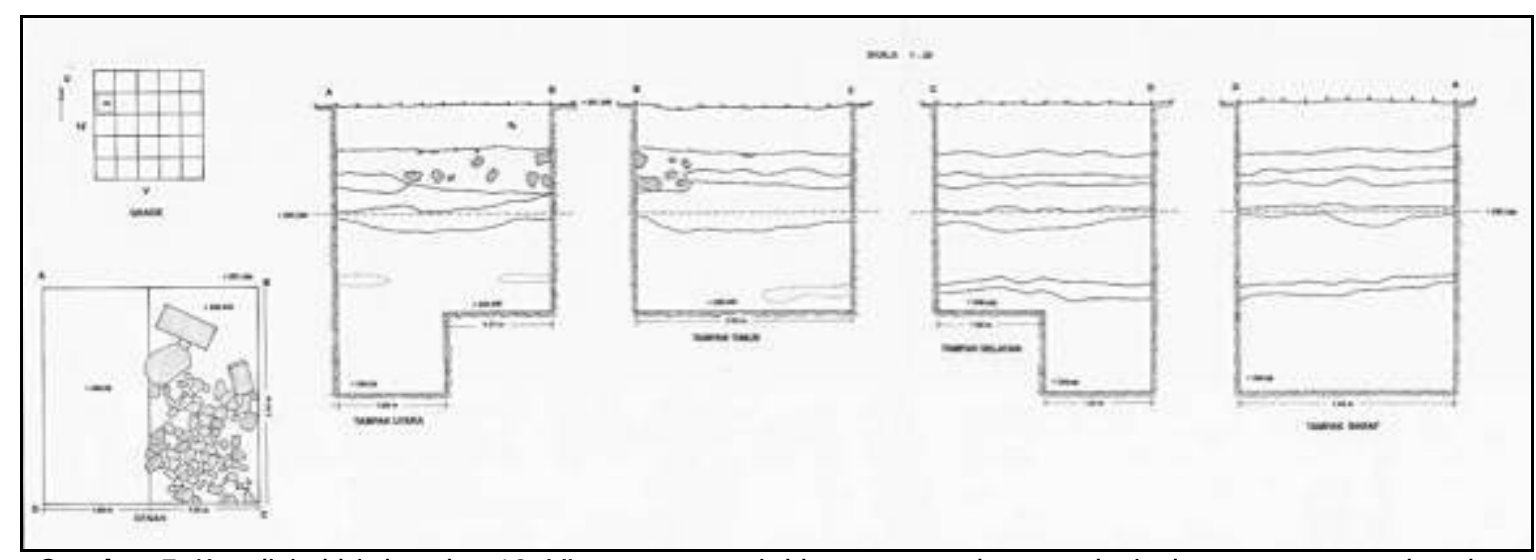

Gambar 5. Kondisi akhir kotak v.12'. VI yang menunjukkan temuan batu andesit dan tatanan pecahan bata pada kedalaman spit 9 di bawah lapisan abu vulkanik (ditandai dengan garis putus-putus pada gambar stratigrafi)

(Sumber: Tim Penyusun 2012)

\begin{abstract}
Beberapa penelitian telah mengungkapkan bahwa Candi Borobudur dibangun dan digunakan pada kurun abad IX-X M. Kesimpulan tersebut didasarkan pada analisis terhadap bentuk arsitektur candi, relief, serta telaah terhadap prasasti Kayumwungan (824 M) yang dipercaya berisi tentang pembangunan Candi Borobudur (Casparis dalam Soekmono 1974, 172). Dengan demikian, dapat disimpulkan bahwa fragmen gerabah yang ditemukan berasal dari abad IX-X $M$. Hal ini juga diperkuat dengan temuan beberapa fragmen keramik Cina pada lapisan yang sama dengan temuan fragmen gerabah tersebut. Temuan fragmen keramik Cina menunjukkan ciri khas keramik dari masa Dinasti Tang hingga awal Dinasti Sung. Dinasti Tang mulai berkuasa pada abad VII M. Maka kita dapat memperkirakan bahwa keramik produksi Dinasti Tang menjadi komoditas umum di Jawa pada abad setelahnya, yaitu abad VIII M. Sementara Dinasti Sung mulai berkuasa pada awal abad X M.
\end{abstract}

\section{Konteks Budaya Temuan Gerabah di Situs Borobudur}

Kegiatan ekskavasi yang dilakukan di Situs Borobudur pada tahun 2012 berlokasi di sisi barat daya candi. Saat ini lokasi tersebut merupakan sebuah lapangan yang disebut sebagai lapangan Gunadharma. Pada tahun 1970-an lahan ini menjadi salah satu daerah yang diolah untuk pengembangan taman wisata Borobudur. Ketika itu, lahan ini mengalami perataan dengan penggunaan buldoser, yang menyebabkan terjadinya pengadukan tanah hingga kedalaman $\pm 50-80 \mathrm{~cm}$. Temuan fragmen gerabah pada kotakkotak ekskavasi berada pada kedalaman $\pm 150-160 \mathrm{~cm}$. Temuan tersebut berada di bawah lapisan abu vulkanik, sehingga diperkirakan masih in situ.

Mengenai adanya permukiman di sekitar candi, Sulistyanto (1996, 35) mengungkapkan bahwa candi mempunyai komunitas pendukung, yaitu sekelompok penduduk yang bermukim di sekitar candi. Sekelompok penduduk tersebut dapat berasal dari kalangan rakyat biasa yang memiliki tugas merawat candi, atau para pendeta yang secara rutin memimpin upacara keagamaan. Keberadaan kelompok pendeta di lingkungan candi dapat diketahui dari Prasasti Palah 1197 M (Boechari 2012, 326-327) dan Prasasti Kalasan $778 \mathrm{M}$ yang menyebutkan tentang pendirian vihara untuk bhiksu Buddha Mahayana di sekitar Candi Kalasan (Mochtar 2009, 104).

Sementara itu, keberadaan sekelompok orang yang bertugas mengelola candi dan bertempat tinggal di dekatnya salah satunya dapat diketahui dari Prasasti Kancana 860 M. Prasasti ini menyebutkan pemberian anugrah dari Rakai Kayuwangi kepada Paduka Mpunku i Boddhimimba untuk mendirikan prasada di daerah Bunur Lor dan Asana, 
serta menjadikan daerah tersebut sebagai dharmasima lpas. Selain itu, dua orang anak Paduka Mpunku i Boddhimimba yang bernama Dyah Imbani dan Dyah Anargha diperbolehkan tinggal di daerah sima tersebut, seperti disebutkan sebagai berikut:

III.b.

1. ...ya ta matannyan turun tan pahambal warasanmatanugraha padu-

2. ka sri maharaja. i sira paduka mpunku i boddhimimba an panusuk dharmmasima Ipas irikan i bunur

3. lor mwan ikan in asana. tanemana wunkal astadesanya. makadon panadegana san hyan prasada. sthana

4. nira san hyan arccha boddhapratiwimbanira. pujan anken karttika masa. mwan sthanani wkanira kalih. wka niratuha ja

5. Iu jalu. manaran dyah imbani. wkanira wunsu wadwan manaran dyah anargha. dyah imbani mwan dyah anargha a-

6. ta[h] pramana i san hyan dharmmasima (Boechari 2012, 283)

Terjemahan:

III.b.

1. ...ketika itu secara langsung turunlah..anugrah dari

2. Paduka Sri Maharaja kepada Paduka Mpunku i Boddhimimba untuk menetapkan dharmmasima Ipas di Desa Bunur

3. dan di Desa Asana, yang ditandai dengan penempatan batu di 8 penjuru mata angin. Kemudian didirikannya bagunan Sang Hyang Prasada sebagai tempat bertahta

4. arca Sang Buddha. Pemujaan dilakukan setiap Bulan Kartika. Dan tinggallah di sana dua orang anaknya, yaitu anak laki-lakinya

5. yang bernama Dyah Imbani dan anak perempuan bungsunya yang bernama Dyah Anargha. Dyah Imbani dan Dyah Anargha

6. bertugas memelihara dharmmasima tersebut (diterjemahkan oleh penulis, 2013)

Adanya permukiman di sekitar
Candi Borobudur juga pernah
diungkapkan oleh Poerbatjaraka dengan
berpendapat bahwa kata 'boro' berasal
dari kata 'biara'. Oleh karena itu,
Borobudur berarti 'Biara Budur'.
Keterangan tersebut diperkuat dengan
ditemukannya pondasi batu dan sebuah
genta perunggu besar pada ekskavasi
yang dilakukan di sisi barat laut candi
pada tahun 1952. Menurut Soekmono,
genta tersebut memperkuat dugaan
bahwa pondasi yang ditemukan adalah
sisa-sisa sebuah biara (Mochtar 2009,
110).
Adanya permukiman di sekitar diungkapkan oleh Poerbatjaraka dengan berpendapat bahwa kata 'boro' berasal dari kata 'biara'. Oleh karena itu, Borobudur berarti 'Biara Budur'. Keterangan tersebut diperkuat dengan ditemukannya pondasi batu dan sebuah genta perunggu besar pada ekskavasi yang dilakukan di sisi barat laut candi pada tahun 1952. Menurut Soekmono, genta tersebut memperkuat dugaan bahwa pondasi yang ditemukan adalah 110). 


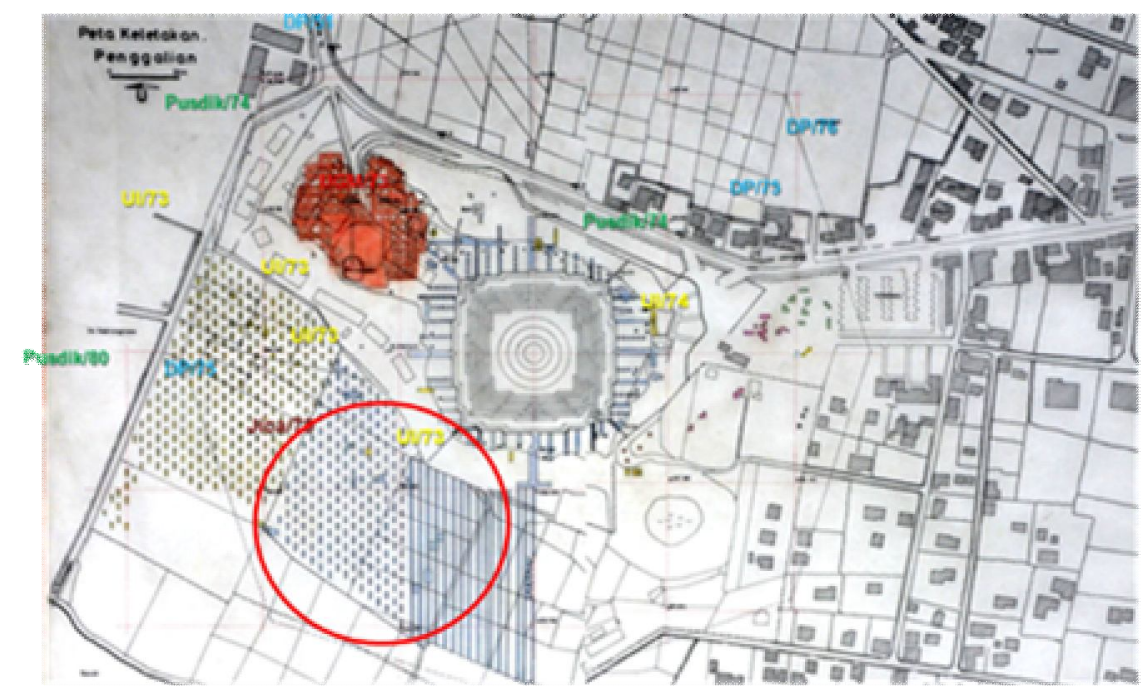

Peta 2. Posisi temuan gerabah (lingkaran merah) yang mengindikasikan letak permukaan kuno di sisi barat daya Candi Borobudur. Daerah yang berwarna merah adalah temuan struktur yang diperkirakan sebagai bekas vihara

(Sumber: Priswanto 2013, 215)

Sementara itu, fragmen gerabah yang ditemukan pada kegiatan ekskavasi 2012 ditemukan di sisi barat daya candi. Berdasarkan posisi keletakannya, sisi barat daya termasuk dalam wilayah belakang dari Candi Borobudur karena pintu masuk berada di sisi timur. Hal ini bukan saja berdasarkan pengaturan arus pengunjung saat ini, tetapi didasarkan pada keletakan relief cerita di dinding candi yang dimulai dari sisi timur. Mengingat bahwa di sisi barat laut pernah ditemukan struktur batu yang diduga sebagai bekas biara (vihara), maka terbuka kemungkinan bahwa sisi barat daya juga masih merupakan bagian dari kompleks biara tersebut. Perkiraan ini juga diperkuat dengan adanya pola yang menunjukkan bahwa permukiman di sekitar candi biasanya terletak di bagian belakang candi, seperti pada Candi Kalasan (Cornelius dalam Mochtar 2009, 105-106) dan Candi Banyunibo, yang keduanya merupakan candi bercorak agama Buddha seperti halnya Candi Borobudur.

\section{PENUTUP}

Kegiatan ekskavasi yang dilakukan di Situs Borobudur pada tahun 2012 ditujukan untuk melacak bekas permukiman di Situs Borobudur. Akan tetapi, dalam kegiatan tersebut tidak banyak ditemukan temuan berupa struktur masif bekas bangunan permukiman. Temuan yang diperoleh didominasi oleh fragmen gerabah, yang juga tidak kalah penting sebagai indikator adanya permukiman kuna di sana. Keberadaan gerabah mengindikasikan bahwa ada sekelompok orang yang beraktivitas di sekitar tempat tersebut, dan dimungkinkan bahwa mereka menetap di sana.

Setelah dilakukan analisis, diketahui bahwa fragmen gerabah tersebut berasal dari berbagai jenis wadah kebutuhan sehari-hari yang diproduksi oleh beberapa desa di sekitar Candi Borobudur. Berdasarkan lapisan stratigrafi tempat ditemukannya diperkirakan fragmen-fragmen gerabah tersebut berasal dari masa yang sama dengan masa pakai Candi Borobudur. Dengan demikian, masyarakat pengguna gerabah tersebut dulunya beraktivitas di tempat ini pada masa Candi Borobudur masih aktif digunakan sebagai tempat pemujaan. Secara spasial, lokasi temuan fragmen gerabah ini berada di sisi barat daya atau di area belakang candi. Lokasinya cukup berdekatan dengan struktur batu yang diduga sebagai bekas biara yang ditemukan di sisi barat laut.

Berdasarkan analisis-analisis tersebut, dapat disimpulkan bahwa temuan fragmen-frragmen gerabah di sisi 
barat daya Candi Borobudur menunjukkan bahwa di tempat tersebut dahulu merupakan bagian dari permukiman kuna. Mengenai aktivitas yang dilakukan di tempat tersebut, belum ditemukan artefak lain selain gerabah yang dapat mengindikasikan bahwa tempat tersebut merupakan tempat tinggal biksu, seperti misalnya pisau cukur atau jarum. Dengan demikian, diperkirakan bahwa permukiman di sisi barat daya ini merupakan wilayah aktivitas profan, baik sebagai bagian dari biara maupun sebagai permukiman tersendiri.

\section{UCAPAN TERIMA KASIH}

Penulis mengucapkan terima kasih kepada Drs. Siswanto, M.A. selaku ketua tim penelitian Situs Borobudur tahun 2012 yang telah memberi kesempatan penulis untuk melakukan analisis terhadap temuan gerabah. Ucapan terima kasih juga disampaikan kepada Prof. Dr. Mundardjito atas arahan dan bimbingannya dalam menangani temuan gerabah ini. Kepada Pokja Penanganan Temuan Balai Arkeologi Yogyakarta; Alifah, S.S., Slamet Widodo, Sri Sutiyanti, M.Si, Dekon Suyanto, dan Hendy S ucapan terima kasih disampaikan atas segala bantuannya dalam melakukan analisis terhadap gerabah dari Situs Borobudur ini. 


\section{DAFTAR PUSTAKA}

Atmosudiro, Sumijati. 1998. 'Manfaat Kajian Gerabah Masa Lalu Bagi Pengembangan Kerajinan Tembikar Sebagai Penunjang Indrustri Pariwisata'. Dalam BERKALA Arkeologi Tahun XVIII Edisi No.2 / November 1998. Yogyakarta: Balai Arkeologi Yogyakarta. HIm. 1-11.

Boechari. 2012. 'Candi dan Lingkungannya' dalam Melacak Sejarah Kuno Indonesia Lewat Prasasti (Kumpulan Tulisan Boechari). Jakarta: Kepustakaan Populer Gramedia. HIm 273-290.

Harkantiningsih, Naniek, dkk (ed). 1999. Metode Penelitian Arkeologi. Jakarta: Pusat Penelitian Arkeologi Nasional.

Mochtar, Agni Sesaria. 2009. 'Vihara Pada Masa Jawa Kuna Abad VIII-XI M (Tinjauan Data Prasasti)'. SKRIPSI SARJANA. Yogyakarta: Universitas Gadjah Masa

Mundardjito. 1978. Preliminary Report on Pottery Found in the Borobudur Site. Badan Pemugaran Candi Borobudur. Tidak diterbitkan.

Nitihaminoto, Gunadi. 1984. 'Pola Hias Gerabah Gunungwingko, Relasinya Dengan Daerah Asia Tenggara dan Cina: Studi Banding Pendahuluan'. Dalam PIA IV Jilid V. Jakarta: Pusat Penelitian Arkeologi Nasional.

Priswanto, Hery. 2013. "Kerangka Acuan Penelitian Melacak Jejak-jejak Permukiman Kuna Pendukung Peradaban Masa Candi Borobudur, Kabupaten Magelang, Jawa Tengah (Tahap II)". Dalam Laporan Kegiatan Evaluasi Hasil Penelitian Arkeologi Balai Arkeologi Yogyakarta Tahun 2013. Tidak diterbitkan.

Soegondho, Santoso. 1995. Tradisi Gerabah di Indonesia: Dari Masa Prasejarah Hingga Masa Kini. Jakarta: Himpunan Keramik Indonesia.

Soejono, R.P. 1984. 'Prehistoric Indonesia'. Dalam Van De Velde (ed.). Prehistoric Indonesia A Reader. Dordrecht: Foris Publication. HIm 49-78.

Soekmono. 1974. 'Candi: Fungsi dan Pengertiannya'. DISERTASI. Jakarta: Fakultas Sastra Universitas Indonesia.

Sulistyanto, Bambang. 1996. 'Permukiman di Lingkungan Candi, Sebuah Model Kajian' dalam Jurnal Penelitian Arkeologi No. 4 Th. II. Yogyakarta: Balai Arkeologi Yogyakarta. HIm. 35-40

http://geounhas06.wordpress.com/minyak-dan-gas-bumi/porositas-dan-permeabilitas/ 
